\title{
THE INFORMATION TECHNOLOGY APPLICATION CHANGE TREND: ITS IMPLICATIONS FOR THE CONSTRUCTION INDUSTRY
}

\author{
Nurshuhada Zainon ${ }^{1}$, Faizul A. Rahim ${ }^{1 *}$, Hafez Salleh ${ }^{1}$. \\ ${ }^{1}$ Department of Quantity Surveying, Faculty of Built Environment, \\ University of Malaya, 50603 Kuala Lumpur, Malaysia. \\ *azli@um.edu.my
}

\begin{abstract}
As technologies change rapidly, improved information technology (IT) products and services are released every day throughout the world. This phenomenon gives tremendous pressure on construction managers to plan, implement and adopt new technology solution in accommodating such changes. However, looking at the tools that can be used to help in this situation, the understanding of the trends of IT change and its impact to the construction industry is essential. Even though most studies in IT change trend have been carried out across industries; however far too little attention has been paid to measure the trend of IT change in construction industry and how fast it has been invented. The purpose of this paper is to explain the implications of IT change and consequently provides an understanding on how IT is changing in construction industry, its current trends, and what are the predictions of its scenario in future construction industry. The study is based on textual reading ranging from 1996 to the first part of 2011, which was gathered from journals, literature books, specialized databases and other information sources available on the Internet. A principal finding is that even though the introduction of new technology in construction is slower than other industries, the implications towards construction industry have significant impacts. This finding provides useful information in order to develop a tool for construction organizations handling the rapid changes by tackling the issues affected by the IT change.
\end{abstract}

Keywords: IT changes, IT trends, IT investment, construction industry, information technology.

\section{Introduction}

Information technologies (IT) will continue to be predominant agents of change within the construction industry (Aouad, Kagioglou, Cooper, Hinks, \& Sexton, 1999; Eadie, Perera, \& Heaney, 2010). The establishment of e-business in the industry such as e-tendering, e-procurement, e-portal, and other electronic transaction process is a proof that there has been a technological shift in construction sector from IT driven solutions to IT enabling ones. Nevertheless, IT environments today are dramatically different from the host-centric systems of 20 years ago. Today, IT systems span complex networks with multiple access points and servers, hundreds of software components and thousands of computing devices (Raad, Yeassen, Alam, Zaidan, \& Zaidan, 2010). 
IT changes rapidly. Due to the e-commerce revolution, it may be changing faster than ever. Customer expectations continue to rise as the level of service in all industries continues to improve. As technology provides the capability to immediately provide information on bank accounts and package shipments, for instance, expectations for similar levels of service in the construction industry are set. Accurate information on project history, status, and financial performance, as well as customer history and projected business must be readily available and accessible to support these expectations and provide a competitive edge. Yet, Froese (1999) claimed that the construction industry lags other industries in its rate of IT adoption. To understand how construction organizations handle the rapidity changes of technology, we must first understand how fast the technology changes and its implications in construction industry. On top of that, this paper gathers the future prediction about IT trend in construction. Understanding this issue is important for both practice and research because of its potential to provide information about how we can manage the technological changes and what is the current strategy to face the challenges.

\section{Methodology}

The data and findings presented in this paper are mostly taken from reviewing the literature. The information was gathered from a range of journals books between 1996 to the first part of 2011. The source materials of the data were obtained from libraries' databases of Malaysian universities. Additionally, specialized databases and other information sources available on the Web have been explored. The selected references were selected based on the well-described methodology, and the research results are available and complete.

\section{Profile of Construction Industry}

The construction sector consists of five main sub-sectors, namely, the design, assembly, manufacturing, supply, clientele, and as well as real estate properties. These sub-sectors run by distinctive parties, and every different project, hence the industry is well known as a fragmented industry. The construction industry is concerned with the delivery and maintenance of residential or commercial buildings, and infrastructure such as roads, railways, airports, bridges, dams and power stations. The production process that facilitates the construction industry involves legal and institutional relationships among clients, architects, engineers, surveyors, planners, contractors, manufacturers and material suppliers. Previously, construction projects involve very tedious process, thus the introduction of IT is a bless for the industry.

\section{Historical Perspective of IT Introduction in Construction Industry}

During the 1980s, personal computers (PCs) were used only in few construction companies (Núria, 2005). In a study on the history of the introduction of IT in construction, Björk (1999) explained that IT was first brought into the construction industry to support activities in creating new 
information. At that time, analysis programs for structural analysis and other similar applications relied on tedious manual preparation of input data, for example, in the form of punched cards. The use of CAD in the construction started during the late of 1980's and it was exclusively used on support for the creation and the viewing of data. Bjork said in his analysis that this early CAD use never achieved the huge productivity gains that the vendors promised. This happened because of early CAD supported communication for limited persons only and the support for information retrieval consisted in several terminals on which the CAD software was running. Furthermore, the software needed very expensive plotters to print the information out.

In the mid of 1990s, 3D-CAD has entered mainstream use (Froese, 1999). The 3D-CAD has established the role of using computer-based building models for design and communication in building projects. To handle 3D file data, the industry data model standards for product models, such as the Industry Foundation Classes (IFC), have been established. The IFC was developed by the International Alliance for Interoperability (IAI). It is used as a basis for the Building Information Modeling (BIM), a 3D model of the building project and a rich source of information shared by all the project participants (Froese, 1999).

During the same period, the introduction of World Wide Web (WWW) in 1993 led to an explosion in Internet usage for commercial uses (Tam, 1999). The WWW provides the graphically based tools for sharing information through computers. The information is accessible 24 hours per day, from any part of the world that equipped with a modem and Internet connection. The physical distance does not become a barrier anymore. Internet service also gives much lower cost than that the IDD and express courier. Communication via e-mail and document sharing via the WWW predominate the Internet, and increasingly Internet has been used for distributed systems and generic data exchange in construction industry (Froese, 1999). Hence, it increases the level of integration among construction software. During the recent years, the use of Internet evolved from static web pages to interactive experiences. WWW today is not only the source of information, but also the way people do business. The revolutionized version of Web 1.0 is known as Web 2.0, and it benefits the construction players by providing collaborative network (Kline, Dolene, \& Turk, 2009).

Virtual Reality (VR) entered construction industry in the early 2000. In this industry, VR is used on the process of design and construction ( $\mathrm{Li}, 2010)$. The basic concept of VR is to model the shape of the objects in 3D, but recently 4D-VR has been introduced which it includes a 3D-CAD model with schedule time as the forth dimension (Dawood, Sriprasert, Mallasi, \& Hobbs, 2001). The first use of VR in the construction sector was the development of walkthrough systems (Bouchlaghem, Thorpe, \& Liyanage, 1996). Nowadays, VR has been applied at different stages of construction developments that includes design phase, such as space modeling, interior design, lighting design, heating ventilation and air conditioning design, fire risk assessment, and landscaping; and in construction phase, for instance site layout and planning, planning and monitoring of construction processes, and evaluation of construction scenarios.

Software-as-a-service (SaaS) has becoming accepted in construction industry since 2006 and this technology is used a lot in Cloud Computing. Since its introduction in 2007 (Vouk, 2008), Cloud 
Computing can be benefited to the construction industry in various aspects. For example architectural design, structural analysis, cost estimating, project planning and control, and procurement management. Cloud Computing refers to Internet based development and services. This technology is still new in the area and it has significant potentials (Gartner, 2008).

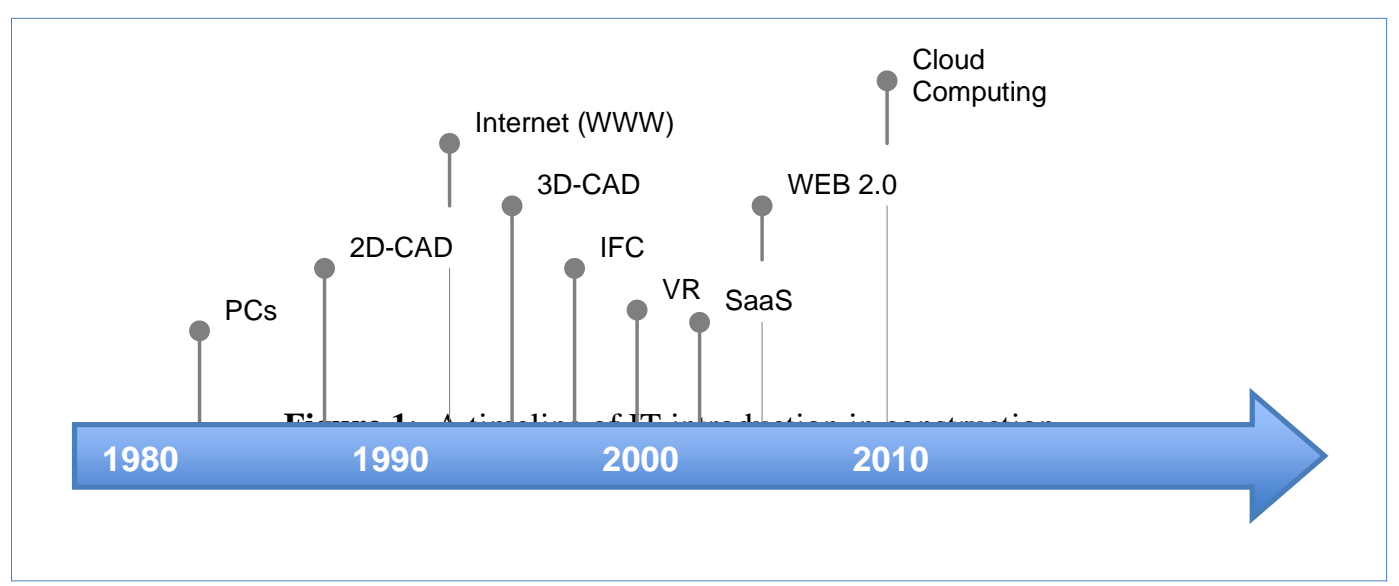

\section{How Fast IT has been Invented?}

There is no empirical study so far about how fast the technology, or specifically IT has been invented. However, it is generally believe that the pace of current technology-driven innovation is so much faster that it was only seven years ago (Brynjolfsson \& Schrage, 2009). Some scholars said that the new technologies and inventions are developed and produced everyday (Jurvetson, 2010; Mezo, 2010). One thing for sure, a technological change is accelerating and it is continually impacting and reshaping the economy, thus business must react quickly to seize the opportunities resulting from change (Please refer to Fig. 2)

As a proof, the number of granted patents ${ }^{1}$ to the new inventions has been increasing year by year as shown in Fig. 3. The statistic shows that the amount of new technologies decreases during the 1990s economic crisis, but the new technologies was still invented. For construction industry, inventions for new technologies is lower than the total amount, however, it is an encouraging number of 18 inventions per year, in average. As technology keeps changing, every generation society changes as new technologies affect everyday life. Thus, how to manage the rapidity of technology change becomes a crucial part in most of the organizations that embrace technology.

\footnotetext{
${ }^{1}$ A patent is an exclusive right granted for an invention, which is a product or a process that provides a new way of doing something, or offers a new technical solution to a problem. A patent provides protection for the invention to the owner of the patent for a limited period, generally 20 years (WIPO, 2011).
} 


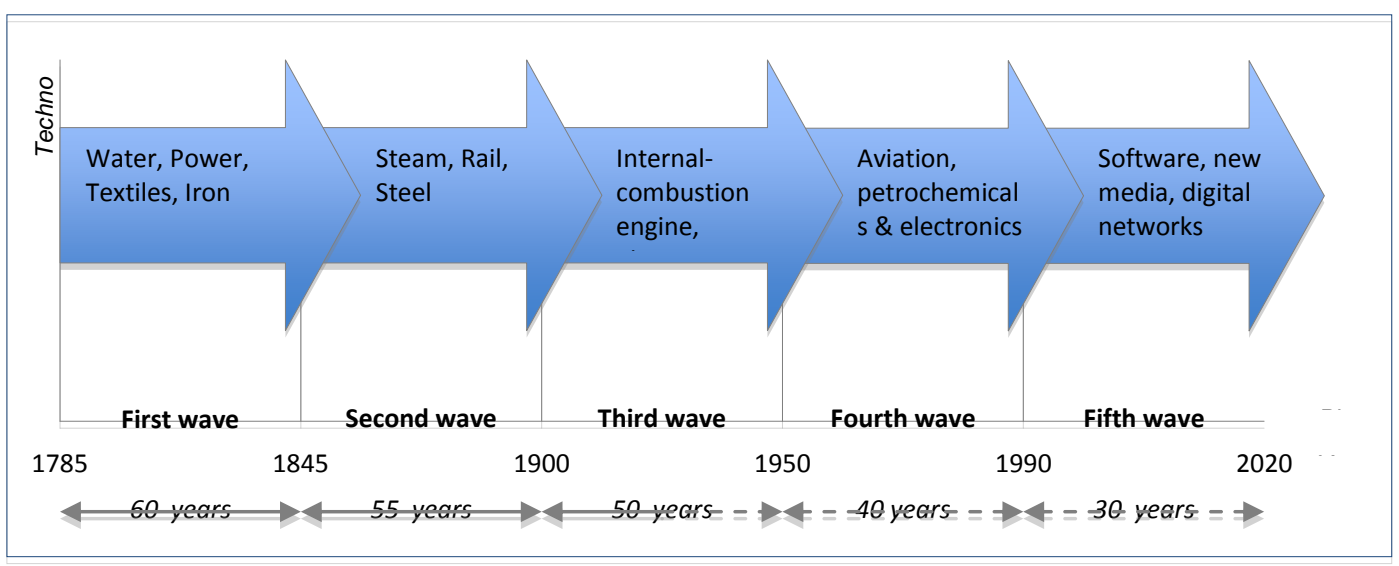

Figure 2: The pace of innovation (The Economist, 1999)

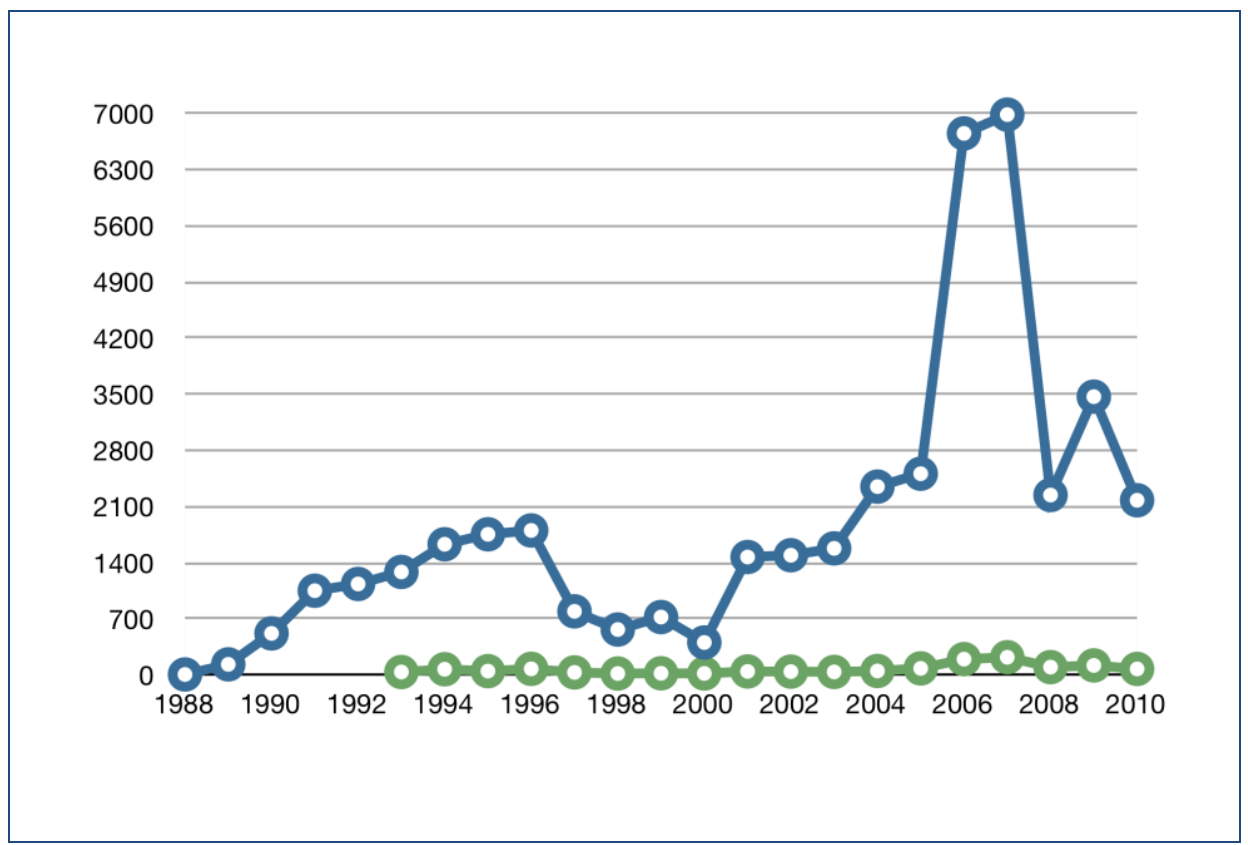

Figure 3: Patents granted from 1988-2010 (MyIPO, 2011)

\section{IT Change Trends in Construction Industry}

Gartner Group (2010) explained in a series of well-followed reports, called "Hype Cycles". The Hype Cycles are management models that help organizations understand the landscape of technology maturity and markets, and to decide which technology innovations to adopt, postpone or ignore, and when is an appropriate time to adopt. It describes the various technologies that address a particular market through five stages, as shown in Table 1.

Table 1: Five stages of market hype cycle (Gartner, 2010).

\begin{tabular}{l} 
Technology trigger \\
$\quad$ A product launch that generates significant press and industry \\
$\quad$ interest. \\
Peak of inflated expectations \\
\hline
\end{tabular}




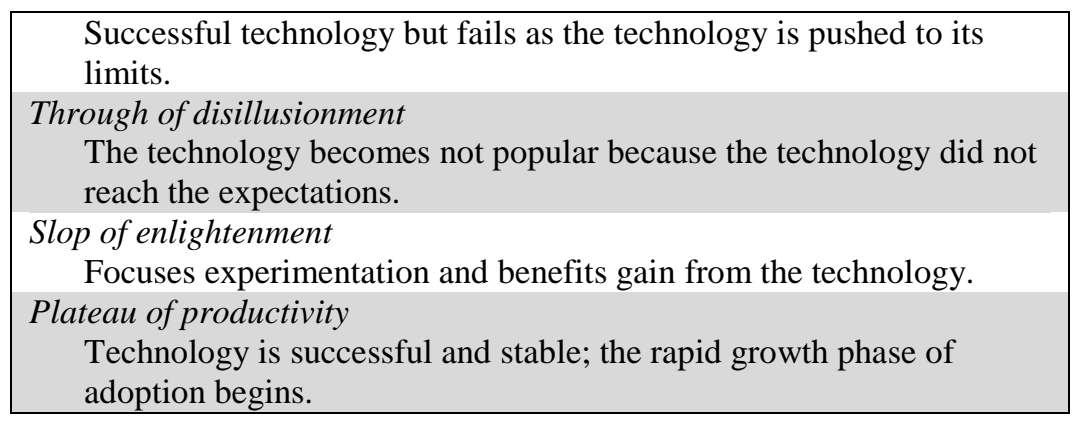

In the Hype Cycle, the Gartner gathered all the existed technologies and allocated them based on the abovementioned stages with the indication of how many years the industries, in general, take time to adopt the technologies. Some technologies will take less than 2 years, many will take 2 to 5 years and 5 to 10 years, and few will obsolete before plateau. Please refer Fig. 4.

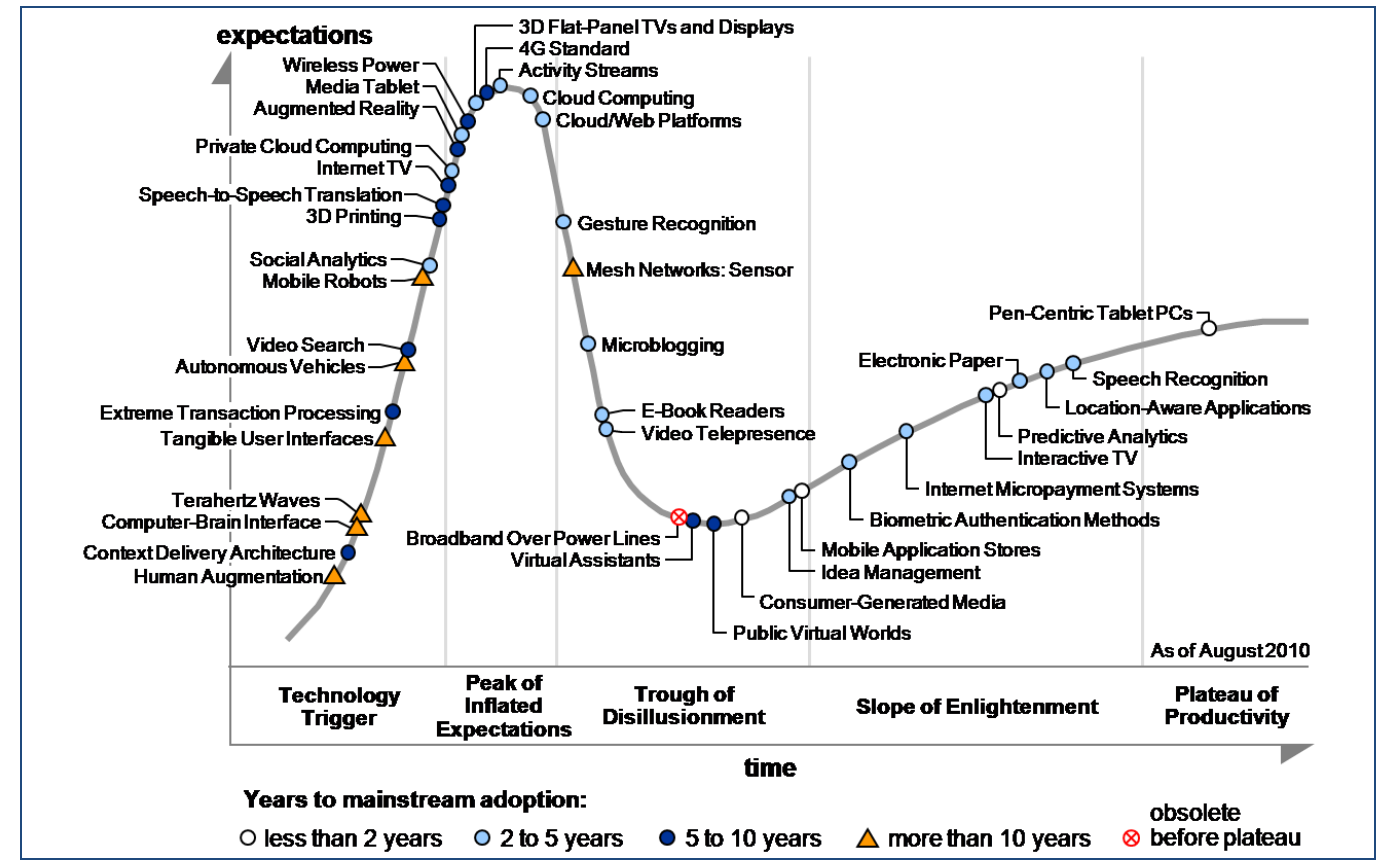

Figure 4: Adopted from The Gartner Hype Cycle (Gartner, 2010)

The changing in technology is also witnessed in the construction industry. The integration of computer based, 3D imagery in the design, planning and construction process is no longer a fancy tool to attract prospective clients, but it already becomes an essential part of a business that cannot be forgone. Those construction organizations that have not embraced this technology run the risk of being outdated and outdone by competitors. However, research regarding IT change trends in this industry is very lacking and limitedly known to the Author. But recently, Erdogan, Abbott, \& Aouad (2010) has made a prediction in their study about how IT will evolve in construction industry in the future based on the STEEP categorization - society, technology, economy, environment, and politics. They concluded that IT would change base on these three strands; people, process, and technology.

Erdogan, et al. (2010) forecast that construction industry in the future will be based on people with a broad range of skills who will use IT skills to underpin the areas in which they are not really 
expert. Hence, IT will enable people having less tedious tasks, leading to more creative and more stimulating work. As a prove, most tasks carried out by manual workers now will be carried out by robots or in factories, which will improve health and safety on site. Likewise, off-site construction will increase. A 'lego-style' construction will be possible through enhancements in IT.

On top of this, IT will streamline processes and it will become more efficient. Intelligent buildings will become mainstream, and it will be possible to manage self-healing/self-correcting buildings through embedded sensors in the buildings. As a result, smarter management of facilities and construction spaces will be seen. In term of project management, it will be carried out more efficiently with better integration of the supply chain, resource management and online transaction processes into the project planning and management tools, and these benefits can be seen today.

In term of technology, IT systems will make it possible to cut down carbon, energy, and cost of climate that enable user-centered design and intelligent built environments. Intelligent or semiintelligent software will improve themselves through automated double-loop learning facilities based on evidence from the actual use of buildings in operation.

\section{IT Investment Trends in Construction Business}

Salleh (2007) has studied the trend of IT investment by looking at IT changes in construction industry according to its business use and investment. His findings show that IT investment trends are divided into 6 stages of maturity. At the first stage, construction organizations start with ad-hoc investment where IT system are developed or purchased based on what the management sees taking place within other external organizations. In the next maturity level, an increased number of IT applications are being used through a small number of IT development plans. Then, short-term development of IT starts to appear with management welcoming user involvement to define needs and requirements. After some time, the management begins to consider the long-term development of IT with an attempt to align business strategy and IT strategy. In level 5 of maturity, the development of IT is used to add value of products or services and also to support supply chain activities, followed by the development of IT that used to support strategic and innovative business objectives in level 6 of maturity.

Table 2: IT infrastructure maturity model according to its business use (Salleh, 2007)

\begin{tabular}{|c|l|}
\hline $\begin{array}{c}\text { Maturity } \\
\text { Level }\end{array}$ & $\begin{array}{c}\text { Strategic thinking and direction towards the development } \\
\text { and utilisation of IT/IS in an organisation }\end{array}$ \\
\hline Level 6 & $\begin{array}{l}\text { STRATEGIC OBJECTIVES } \\
\text { - Drivers; global competition } \\
\text { - System requirements definition: Full in-house with } \\
\text { minimum intervention from company's partners. }\end{array}$ \\
\hline
\end{tabular}




\begin{tabular}{|l|l|}
\hline Level 5 & $\begin{array}{l}\text { ADDED VALUE } \\
\text { — Drivers: partner's supply chain } \\
\text { - System requirements definition; mainly in-house with } \\
\text { intervention from supply chain partners and vendors }\end{array}$ \\
\hline Level 4 & $\begin{array}{l}\text { LONG TERM BUSINESS INVESTMENT } \\
\text { - Drivers: business process improvement } \\
\text { - System requirements definition: mainly in-house with } \\
\text { intervention from vendor. }\end{array}$ \\
\hline Level 3 & $\begin{array}{l}\text { SHORT TERM BUSINESS INVESTMENT } \\
\text { - Drivers: organisation communication } \\
\text { System requirements definition: mainly in-house with } \\
\text { intervention from vendors }\end{array}$ \\
\hline Level 2 & $\begin{array}{l}\text { PROJECT-ORIENTED INVESTMENT } \\
\text { Drivers: work task requirements } \\
\text { - System requirements definition: partially from in- } \\
\text { house and mostly form vendor. }\end{array}$ \\
\hline Level 1 & $\begin{array}{l}\text { AD-HOC INVESTMENT } \\
\text { D Drivers: copying/duplication } \\
\text { System Technical requirements definition: heavily } \\
\text { depends on vendor }\end{array}$ \\
\hline
\end{tabular}

\section{8. $\quad$ Future IT Trends in Construction}

Among people who work in the field of computer technology, it is fairly routine to speculate about the likelihood that computers will someday approach, or possibly even exceed, human beings in general capability and intelligence. Ray Kurzweil expects computers to become at least as intelligent as humans by the year 2029 (Ford, 2009, p. 2). Nevertheless, the Forrester analysts recently predict future IT trends in construction will be in this four categories; "empowered" technology, process-centric data and intelligence, flexible applications, and smart technology management (Leganza, Cullen, \& An, 2010b). Base on these, Saas and Cloud Computing will be the greatest impact on construction industry (Leganza, Cullen, \& An, 2010a). On top of this, other technologies that will bang the industry are information-as-a-service (IaaS), Building Information Model (BIM), and next-generation Business Intelligence (BI), and others current technology will be in a mature phase (Erdogan, et al., 2010; Gartner, 2011; McGrawHill, 2009).

On top of this, Megat-Rus-Kamarani (2002) listed a number of future IT-related characteristics of construction industry based on the assumptions about emerging IT trends. He mentioned that these characteristics should be given priority now to make the industry ready for the 
future. The first, is that safe and secure IT policy will be set up, and networking with R\&D centers worldwide to develop competitive knowledge and to get updates on new inventions.

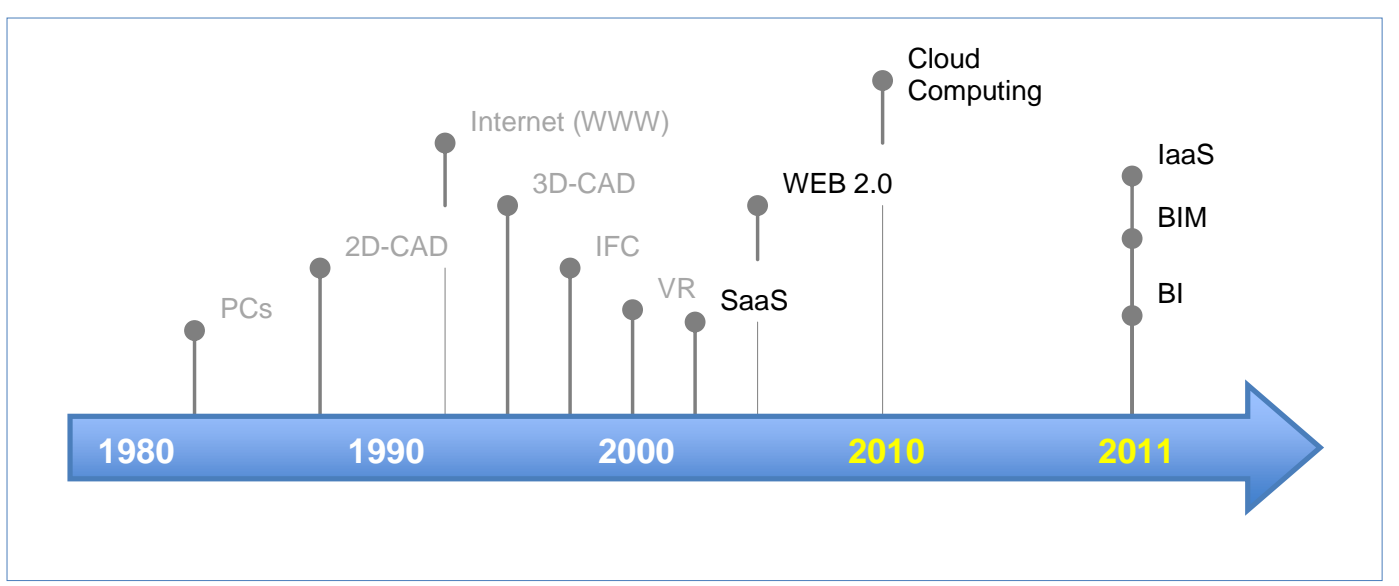

Figure 5: Predicted future IT trends in construction industry.

\section{Implications of Rapid Change in IT}

The introduction of new IT has apparently benefited the world in many ways such as upgrading people's lifestyle and their mode of doing work. The information transfer nowadays become faster than years ago and it enables companies to invest in a wide range of ventures around the world. At the same time, the interconnection between sectors in an industry become closer (Wangwe, 1995). Furthermore, technological changes increases people interest in knowledge discovery and developing new ideas and this creates healthy environment for future generation, like for example, people have started to expand idea management.

Despite these, the rapidity of technology changes implicates the world in negative perspective as well. If IT changes is not properly managed, it could become a burden to any organizations. As new IT must be absorbed, mastered, and controlled, this demands the ability to apply new ideas and practices that in turn require abstract thinking, problem solving and inference (Montealegre, 1998). The list of implications of the rapidity changes in IT can be referred to Table 3.

Table 3: Implications of the rapidity change in IT

\begin{tabular}{|l|l|l|}
\hline \multicolumn{1}{|c|}{ Factor } & \multicolumn{1}{c|}{$\begin{array}{c}\text { Impact } \\
\text { (Benamati \& Lederer, 2001; } \\
\text { Shakantu, Zulu, \& Matipa, 2002) }\end{array}$} & \multicolumn{1}{c|}{ Effects } \\
\hline Technology & $\begin{array}{l}\text { Information flows faster through all } \\
\text { aspects of the construction industry } \\
\text { (design, construction, finance, } \\
\text { marketing etc.) }\end{array}$ & $\bullet \begin{array}{l}\text { Companies who have IT gain } \\
\text { the competitive advantage. } \\
\text { Increase turnover in investing } \\
\text { new IT and send staffs for } \\
\text { training. }\end{array}$ \\
& Rective communication worldwide. & $\begin{array}{l}\text { Increase a risk of overhead if } \\
\text { the new IT failure. } \\
\text { New IT can become obsolete }\end{array}$ \\
\hline
\end{tabular}




\begin{tabular}{|l|l|l|}
\hline & monitoring. & $\begin{array}{l}\text { before its initial use due to } \\
\text { lengthy duration of IT } \\
\text { acquisition. }\end{array}$ \\
& Reduce transactions costs. & $\begin{array}{l}\text { Difficulties in knowing the } \\
\text { differences between new IT } \\
\text { and choosing most } \\
\text { appropriate. }\end{array}$ \\
\hline Nature of market & $\begin{array}{l}\text { Construction companies know more } \\
\text { about latest construction product. }\end{array}$ & $\begin{array}{l}\text { They have become more } \\
\text { demanding about price and } \\
\text { quality. }\end{array}$ \\
& $\begin{array}{l}\text { They have a free market from } \\
\text { which to choose contractors } \\
\text { from. }\end{array}$ \\
\hline Globalization & $\begin{array}{l}\text { International contractors enter the } \\
\text { local market. }\end{array}$ & $\begin{array}{l}\text { Increase competition for local } \\
\text { contractors. }\end{array}$ \\
& $\begin{array}{l}\text { Interconnectedness between sectors } \\
\text { grows (Wangwe, 1995). }\end{array}$ & $\begin{array}{l}\text { Local contractors require an } \\
\text { international credibility. }\end{array}$ \\
& $\begin{array}{l}\text { Number of workers involved in } \\
\text { knowledge discovery and application } \\
\text { grows. }\end{array}$ & $\begin{array}{l}\text { IT managers cannot be } \\
\text { New and varied IT requires IT } \\
\text { professionals continuous training. }\end{array}$ \\
\hline People & $\begin{array}{l}\text { Turnover generates additional } \\
\text { training demands (Benamati } \\
\text { \& Lederer, 2001). }\end{array}$ \\
\hline
\end{tabular}

\section{Strategic Actions to Face IT Changes}

Generally, the ability of most construction industries to manage change has been the subject of controversy and debate for many years (Shakantu, et al., 2002). This industry has been considered as unresponsive to change. Yet, several attempts have been made to deal with such situation. In this context, the issues of culture change and customer service within organizations have been addressed (Haymes, 2008; Hsiao \& Ormerod, 1998; Jackson \& Philip, 2010; Koehn \& Adler, 2010). Today, it is a critical time for construction management to confront the challenges of change. The construction should be prepared for the future in facing IT changes. Therefore, the following strategies are recommended to the construction industry.

\section{A. Accelerate research \& development $(R \& D)$}

Construction industry is among the largest and most influential industry in the world, yet it spend only a small percentage of its expenditure on research (Megat-Rus-Kamarani, 2002). This lack of research has been provided as a reason for the diminished competitiveness of this industry. Therefore, by improving the number of people involved in the discovery of new technology, construction industry will produce its own technology rather than adopting it from other industries where adoption will take a longer period. Furthermore, the industry will understand more which technology that suits them and therefore, it will be using for a longer time.

\section{B. Benchmarking}


Benchmarking helps construction organizations to achieve greater performance through careful selection and manipulation of alternatives, comparison measures, and standardization of key delivery of best practices. Construction managers will be familiar with the IT trends, hence they will know what and which element of IT infrastructure they should invest in.

\section{Knowledge Management}

Practicing knowledge management in construction organizations should be encouraged. Leveraging knowledge for competitive advantage by solving problems using special knowledge based diagnostic systems (Hope \& Hope, 1997). This exercise enables an organization to monitor the performance of the IT system and its value added to business units and teams.

\section{Training and development}

Intellectual capital is an important factor in the success of a company. Having appropriately skilled IT personnel is important to make sure they capable to use new IT and maximize the technology for the construction industry benefits. They also must be aware of the latest technology so that they can propose to the company the work for, at the same construction organizations could maintain their competitive advantage.

\section{E. Flexible infrastructure}

At times, it is difficult to choose which IT suits best for a company, therefore by having a flexible IT infrastructure, it will reduce the cost of re-developing new technology and safe time for introducing it to the organization. Flexibility in infrastructure means that system must be able to adapt to changes without the company need to re-invest in buying new technology, and the system must be easily reconfigured and compatible with other systems that have been used.

\section{Conclusions}

The world has witnessed the development of many technological advances in the construction industry. After 30 years of IT been introduced to construction industry, this study shows that the industry now is facing a great challenge due to the fast change of technology. In general, this study may reflect the advancement of information technology in developed countries due to available published studies has limited scope within that range. However, one thing for sure, the construction industry will see a great advancement of IT in the future. Even though the trend of new technology inventions in construction industry is slower compared to others, it still impacts the construction organizations tremendously. For this reason, construction industry definitely needs to prepare and arrange IT strategies focusing on long-term cost savings, time saving, increase effectiveness and competitive advantage

\section{Research contributions}


The rapid evolution of IT is transforming the construction industry. Therefore, the findings of this study are important for a better understanding of IT change trends in construction. Construction managers could use this information as a preparation for them in facing technological changes. By understanding the IT change trends, it helps construction managers to choose which IT system their companies should embark, and they also could predict time when is the later technology will be introduced. Hence, it helps them in their cash flow.

On the other hand, this study lists the implications of the rapidity of IT changes. This finding provides potential information in assisting the development of company's strategies in managing their IT. In term of knowledge contribution, the finding opens opportunities in research and development that the industry could uptake and cooperation could be done internationally.

\section{Future research}

The authors' goal for future research is to develop a model, a framework, or a matrix, as a tool for construction organizations to deal with the rapid changes of IT. The tool will be a blended process from an extensive literature reviews and expert opinion and will further enhance through pilot study, case studies and large survey. It tool will focus at cost-effectiveness, fast and efficient process. However, in order to develop this tool, a study on current practices by various industries is needed. The advantages and limitations of the available tools must be acknowledged, and therefore a new tool can be adapted from it, which can be very useful for construction organizations. The tool also is expected in evaluating the construction organization's strategies and opportunities resulting business value through increased IT effectiveness.

\section{Acknowledgement}

This research has been supported by grants from the Institute of Research Management and Consultancy (iPPP) of the University of Malaya. We appreciate the critical remarks of anonymous reviewers, and the many who generously gave of their time to comment on drafts of the manuscript. All errors are the sole responsibility of the authors.

\section{References}

Aouad, G., Kagioglou, M., Cooper, R., Hinks, J., \& Sexton, M. (1999). Technology managent of IT in construction: A driver or an enabler? Logistics Information Management, 12(1/2), 130-137.

Benamati, J., \& Lederer, A. L. (2001). Rapid IT change, nine IT management challenges. INFOR 8(4), 336-358.

Björk, B. C. (1999). Information technology in construction: domain definition and research issues. International Journal of Computer Intergrated Design and Construction, 1(1), 1-16.

Bouchlaghem, N., Thorpe, A., \& Liyanage, I. G. (1996). Virtual reality application in the UK's construction industry. Retrieved 24 February, 2011, from 
http://docs.google.com/viewer?a=v\&q=cache:P3411GCGroAJ:itc.fgg.uni-

lj.si/bled96/papers/bouchlag.pdf+VR+in+construction+industry\&hl=en\&gl=my\&pid=bl\&srci d=ADGEEShAd5kjjaU38RF-34mE5tF79ofDxry1bz-GMZrqLNmU0J4pRCKVl-

J5eZuIaD2i9n1v-LoXrunNs-7euFu-G-F176Bz8PtA-My2i9gdMEDUEna0p1dbWIa95GQIbnwlfSanhJk\&sig=AHIEtbSA2jD3qu3ubb0_MUXNidqRpI $\underline{\mathrm{X} 2 \mathrm{iQ}}$

Brynjolfsson, E., \& Schrage, M. (2009). The new, faster face of innovation. 2011(1 March). Retrieved from http://sloanreview.mit.edu/executive-adviser/articles/2009/3/5139/the-new-faster-faceof-innovation/

Dawood, N., Sriprasert, E., Mallasi, Z., \& Hobbs, B. (2001, 4-5 October). Development of an integrated information resource base for $4 D / V R$ construction processes simulation. Paper presented at the AVR II and CONVR2001, Chalmers, Gothenburg, Sweeden.

Eadie, R., Perera, S., \& Heaney, G. (2010). Identification of e-procurement drivers and barriers for UK construction organisations and ranking of these from the perspective of Quantity Surveyors. ITcon, 15(23-43).

Erdogan, B., Abbott, C., \& Aouad, G. (2010). Construction in year 2030: developing and information technology vision. Philosophies Transactions of The Royal Society. Retrieved from http://rsta.royalsocietypublishing.org/content/368/1924/3551.full

Ford, M. (2009). The lights in the tunnel - Automation, accelerating technology and the economy of the future. United States: Acculant Publishing.

Froese, T. (1999). Interwoven threads: Trends in the use of information technologies for the construction industry, A white paper prepared for the Berkely-Stanford CE\&M Workshop.

Gartner. (2008). Gartner says Cloud Computing will be as influential as e-business. Retrieved from http://www.gartner.com/it/page.jsp?id=707508

Gartner. (2010). Gartner's Hype Cycle Special Report for 2010. In J. Fenn, B. Gammage \& M. Raskino (Eds.): Gartner Group.

Gartner. (2011). Predicts2011: Gartner's predictions for the year ahead. Retrieved 24 February, 2011, from http://www.gartner.com/technology/research/predicts/

Haymes, T. (2008). The Three-E Strategy for Overcoming Resistance to Technology Change.

Educause Quarterly, 31(4). Retrieved from

http://www.educause.edu/EDUCAUSE+Quarterly/EDUCAUSEQuarterlyMagazineVolum/Th eThreeEStrategyforOvercoming/163448

Hope, J., \& Hope, T. (1997). Competing in the third wave: The ten managemnet issues of the information age. Boston, USA: Harvard Business School Press.

Hsiao, R. L., \& Ormerod, R. J. (1998). A new perspective on the dynamics of information technology enabled strategic change. Information Systems Journal, 8(1), 21-52.

Jackson, S., \& Philip, G. (2010). A techno-cultural emergence perspective on the management of techno-change. International Journal of Information Management, 30, 445-456. 
Jurvetson, S. (2010). The pace of innovation never falters. Technology Review by MIT. Retrieved from http://www.technologyreview.com/business/24562/

Kline, R., Dolene, M., \& Turk, Z. (2009). Possible benefits of Web 2.0 to COnstruction Industry. Paper presented at the International Conference on Information Technology in Construction, Santiago, Chile.

Koehn, D. J., \& Adler, R. (2010). CALM (change, adaptin, learning model) - Dealing with change holistically and dynamically. Retrieved from http://www.articlesbase.com/managementarticles/calm-change-adaptation-learning-model-dealing-with-change-holistically-anddynamically-2463039.html

Leganza, G., Cullen, A., \& An, M. (2010a). The Top 15 Technology Trends EA Should Watch: 2011 to 2013. Forrester Research.

Leganza, G., Cullen, A., \& An, M. (2010b). The top 15 technology trends EA should watcha: 2011 to 2013. Forrester Research.

Li, M. (2010). Applications of virtual reality technology in construction industry. Paper presented at the 2nd International Conference on Computer Engineering and Technology (ICCET) 2010.

McGrawHill. (2009). SmartMarket Report, the business value of building information modeling: getting building information modeling to the bottom line.

Megat-Rus-Kamarani, M. K. A. (2002). Reforming Malaysian construction technology to higher dynamism. Paper presented at the Asian Forum 2002 for the Field of Architecture and Building Construction.

Mezo. (2010). Amazing technology: New amazing technologies. Retrieved 1 March, 2011, from http://hubpages.com/hub/Amazing-technology

Montealegre, R. (1998). Managing information technology in modernizing 'against the odds': Lessons from an organisation in a less-developed country. Information \& Management, 34, 103-116.

MyIPO. (2011). Intellectual Property Corporation of Malaysia: Patent Statistics. Retrieved 1 March, 2011, from

http://www.myipo.gov.my/index.php?option=com_content\&view=article\&id=160\&Itemid=3 27

Núria, F. M. (2005). Life cycle document management system for construction. University Politechnic of Catalunya, Catalunya.

Raad, M., Yeassen, Alam, G. M., Zaidan, B. B., \& Zaidan, A. A. (2010). Impact of Spam Advertisement through email: A Study to Assess the Influence of the Anti-spam on the Email Marketing African Journal of Business Management, 4(11), 2362-2367.

Salleh, H. (2007). Measuring Organisational Readiness Prior to IT/IS Investment. University of Salford, Salford.

Shakantu, W., Zulu, S., \& Matipa, W. (2002). Global drivers of change: Their implications for the Zambian construction industry. Paper presented at the CIB W107 1st International Conference: Creating a sustainable construction industry in developing countries, Stellenbosh, South Africa. 
Tam, C. M. (1999). Use of the internet to enhance construction communication: Total Information Transfer System. International Journal of Project Management, 17(2), 107-111.

The Economist. (1999). Innovation in industry: A survey. The Economist, 20 February.

Vouk, M. A. (2008). Cloud computing - issues, research, and implementations. Journal of Computing and Information Technology, 16(4), 235-246.

Wangwe, S. M. (1995). New technologies and the implications of changing technological conditions Exporting Africa: Technology, trade and industrialization in Sub-Saharan Africa. London: Routledge.

WIPO. (2011). World Intellectual Property Organisation. Intellectual Property - some basic definitions Retrieved 1 March, 2011, from http://www.wipo.int/aboutip/en/studies/publications/ip_definitions.htm 